\title{
Philosophy in the Design of River Training Works
}

\section{The Hung Nguyen*}

Department of Water Resources Engineering, University of Science and Technology, The University of Danang, Vietnam

*Corresponding Author: The Hung Nguyen, Department of Water Resources Engineering, University of Science and Technology, The University of Danang, Vietnam.

The stabilization of river system is crucial in socio-economic development, especially in agricultural development, for example irrigation water withdrawal, flood drainage to reduce the impacts of flooding on crop production, etc.

Rivers are becoming increasingly unstable due to changes in topographic, hydrological regimes and sedimentation conditions. River channel migration is mainly driven by deposition, bank erosion and meander cut-off, etc.

Localized river training works such as revetments, dykes or groynes are usually implemented for bank stabilization against erosion.

A successful localized river training work is a structure that not only enables protection against localized erosion solely at the construction location but also can stabilize the whole river system.

A localized river training work is a structure designed to protect riverbanks against erosion which is built at a specific position along the river, for example on concave bank, where velocity is high that leads to erosion on the outer bank.

Therefore, the design of sustainable river training works that can meet the above-mentioned goals is a challenging task.

A philosophy that must be throughout in the design of the river training work is that all components within a river training work must be sustainably linked with each other in term of space and time.

For example, to ensure that a groyne in a localized river training work can function normally for a long-term duration, its parts need to be sustainably linked both in terms of space and time, under the influence of the flow (velocity, pressure, water level). On the contrary, if either (i) a part of the groyne is detached from the groyne by flow or (ii) the original spatial position of the groyne is changed, then the training work will not work safely in a longterm operation as the design expectation. These two conditions are elaborated as follows:

\section{A part of the groyne is detached from the groyne by} flow: If a part of the groyne is detached, this will obviously impact on the normal working condition of other parts of the groyne, for example, if the toe reinforcement is separated from the groyne, obviously the groyne will become unstable;

2. Changes of the original spatial position of the groyne: Any groyne in the series of groyne protects against erosion of the curved river, if the position in space of groynes is changed (e.g. due to localized subsidence) then the effectiveness of groynes to protect the curved river against erosion would be diminished, thus resulting in the erosion of concave bank.

In summary, a design of a river training work is recommended to comply this philosophy for a long-term sustainability.

\section{Assets from publication with us}

- Prompt Acknowledgement after receiving the article

- Thorough Double blinded peer review

- Rapid Publication

- Issue of Publication Certificate

- High visibility of your Published work

Website: www.actascientific.com/

Submit Article: www.actascientific.com/submission.php Email us: editor@actascientific.com

Contact us: +919182824667 